\title{
Evaluation of Materials Related to Gender-Preferences for the Application of Cooperative Robot Skin
}

\author{
Minhee Son, Dongwon Shin, Caroline Sunyong Lee ${ }^{\dagger}$ \\ Department of Materials and Chemical Engineering, Hanyang University, Ansan-si, Gyeonggi-do, 15588, Republic of Korea
}

\section{협동 로봇 스킨에 적용하기 위한 재료의 성별 선호도와 관련된 자료 조사}

\author{
손민희, 신동원, 이선영 \\ 한양대학교 재료화학공학과
}

\begin{abstract}
본 연구에서는 일반적으로 협동 로봇의 스킨으로 사용될 수 있는 고분자 재료 선정 및 기계적 특성 검사를 진행하고, 각 재료에 대한 성별 선호도 설문조사를 진행하였다. 조사는 20 30세의 근무자 225명(남: 124명, 여: 101명)을 대상으 로 작업 중 로봇과 가장 많이 접촉하는 어깨, 팔꿈치 별로 선정된 Dragon-skin, Ecoflex, 및 polydimethylsiloxane (PDMS)에 대한 성별에 따른 선호도 조사로 진행하였다. 설문은 각각 설문자들이 느끼는 재료에 대한 인식 단단함, 끈 적임, 익숙함, 선호도 4종류로 구분하여 진행되었고, 단단함과 끈적임은 각각 재료의 변형률과 접촉각으로 측정되었다. 선호도 조사 결과, 여성은 변형률이 작은, 더 단단한 재료를 선호하는 반면, 남성은 변형률이 큰 부드러운 재료를 선 호했다. 성별에 따른 선호도와 관련하여 재료의 특성을 평가한 결과, 여성은 끈적임이 낮고 변형률이 낮은 Dragon-skin 을 선호하는 경향이 있는 반면, 남성은 끈적임에 관계없이 변형률이 높은 Ecoflex를 선호하는 경향이 있음을 확인하였 다. 따라서 이러한 결과는 협동 로봇 스킨 제작을 고려할 때 재료 선택에 기준이 될 것으로 보인다.
\end{abstract}

\begin{abstract}
This study evaluated gender preferences regarding the mechanical properties of polymers that are typically used as cooperative robot skin. Gender-based preferences of workers aged 20 30 and polydimethylsiloxane were examined according to the body parts which is most frequently in contact with the robot during operation. The factors influencing preference, i.e., stiffness and stickiness, as measured by strain rate and contact angle, respectively, were analyzed to compare genderbased differences. Female preferred stiffer materials with small strain rates while male preferred softer materials with large strain rates. As a result of evaluating mechanical properties of the materials to relate to gender-based preference, we found that female tended to prefer Dragon-skin with the lowest stickiness, and a low strain rate, during compressive creep tests. In contrast, male tended to prefer Ecoflex with high strain rate regardless of stickiness. Therefore, these results provide basis for material selection when considering cooperative robot skin.
\end{abstract}

KEYWORDS: Gender-based preference, Cooperative-robot skin, Contact angle, Strain rate

\section{Introduction}

Robots have been used widely in various manufacturing industries over the past few decades, and several companies

\footnotetext{
†To whom correspondence should be addressed.

E-mail: sunyonglee@hanyang.ac.kr

Received: 26 February 2021, Revised: 26 March 2021,

Accepted: 14 April 2021
}

use cooperative robots in conjunction with human workers to reduce labor costs. Conventionally, cooperative robots are made of metal, which is fairly strong, but its hard surface can injury to a human coworker in the event of collision.

In recent years, unlike industrial robots, cooperative robots are capable of various functions, such as automatic stop in case of collision with humans. However further humanfriendly improvement is needed, considering ergonomic factors. For example, its hard surface can cause human workers 


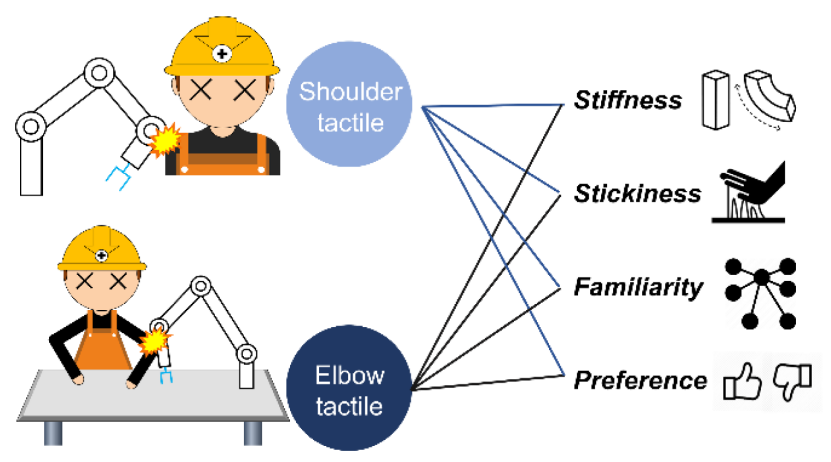

Figure 1. Schematic diagram showing how the survey was conducted

feel uncomfortable. To solve this problem, many studies were done to evaluate soft and flexible materials for robot skin (Kim et al., 2015; Pang et al., 2018; Taisuke et al., 2008; Jeong et al., 2020). However, they have not considered emotional interaction between human workers and robots. Since physical interaction between human worker and robot plays an important role in robotics, selecting preferred material is crucial (Yamashita et al., 2019).

Therefore, this study aims to investigate emotional interaction between robotics and humans who are in contact with Robot skin to find its preference of materials according to age and gender of people working in the same space as cooperative robots. Depending on the type of industry, workers can be grouped by gender. For example, workers in semiconductor fabrication and mobile phone assembly facilities are mostly female since this industry required delicate processes for electronic production. In contrast, most of the workers in automobile assembly and production facilities are mostly male (Roos, 1985). Therefore, as indicated in Table 1, the preference survey classified workers by gender. Moreover, during semiconductor fabrication processes when workers are operating above the chest level, main contact between cooperative robots and humans is most likely to occur at shoulder level. Other processes involving body contact are most likely to contact at elbow level. Moreover, in order to measure the degree of preferences, three properties including stiffness, stickiness and familiarity were selected as the factors that may influence the preference (Kim et al., 2019; Shimizu and Nonomura, 2018; Shirado et al., 2006, Yamashita et al., 2019).

Stiffness and stickiness, as mentioned in this paper, can be used as the indicator for the degree of rigidity and stickiness respectively how the participants feel in contact with the material sample while familiarity is an indicator people have experienced each sample in the past.

Considering that cooperative robots work close with humans, we have selected materials for robot since that are harmless to the human body with no strong odor to be used for the cooperative robot skin material. Among various materials, we have chosen Dragon skin, Ecoflex and polydimethylsiloxane (PDMS) as the skin materials in this study since they are highly flexible and harmless. Dragon skin ${ }^{\mathrm{TM}} 30$ (smooth-on, USA) and Ecoflex ${ }^{\mathrm{TM}}$ 00-30 (smooth-on, USA) are types of silicon rubbers, which have been conventionally used for the special effect masks and makeup. These materials are biologically inert, opaque, and almost odorless. Finally, PDMS (Sylgard, 184; Sewang Hitech, Korea), has selected in this study since PDMS is used in wide range of applications ranging from contact lenses to cosmetics, food, and lubricants (Lin et al., 2014; Berthiaume et al., 1999; Bongaerts et al., 2007; Gerde et al., 2011; Goddard et al., 1999), and they are optically clear, inert, and non-toxic.
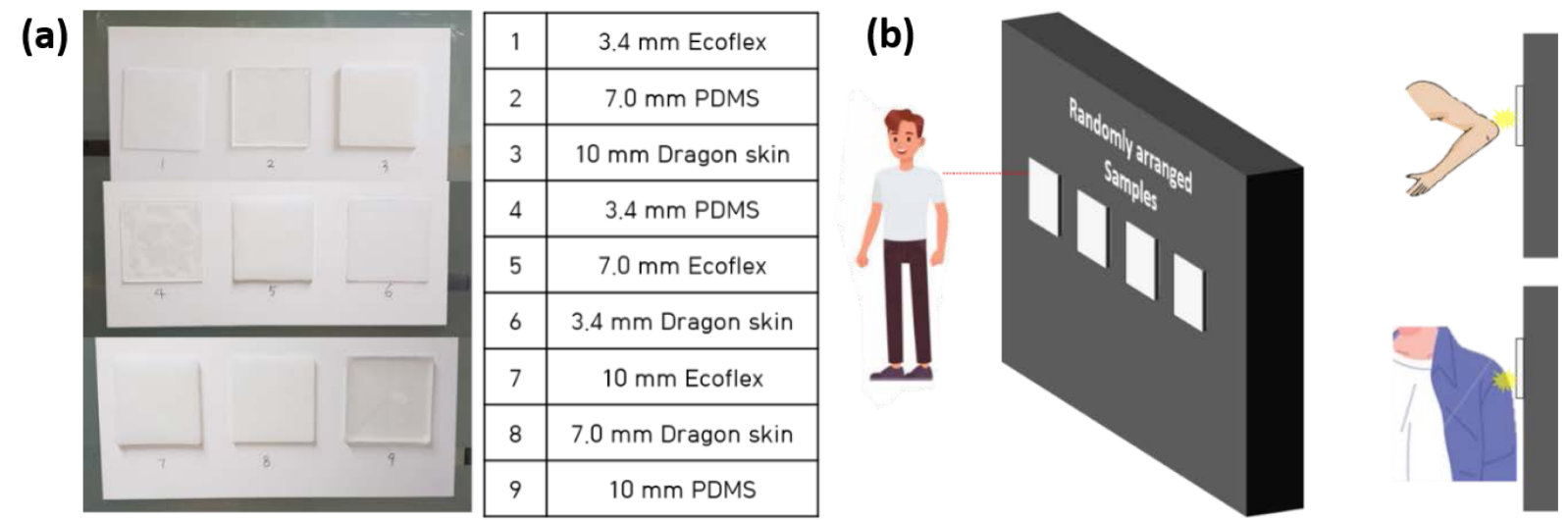

Figure 2. (a) Order of robot skin tested and (b) schematic of how the experiment was performed 
Table 1. Maximum and minimum mean and its standard deviation for each factor as a result of preference survey.

\begin{tabular}{|c|c|c|c|c|c|}
\hline \multirow{2}{*}{\begin{tabular}{c} 
Preference survey results \\
\cline { 2 - 6 }
\end{tabular}} & \multicolumn{2}{|c|}{ Shoulder } & \multicolumn{2}{c|}{ elbow } \\
\hline \multirow{2}{*}{$\begin{array}{c}\text { Stiffness } \\
\text { (survey results } \\
\text { with standard } \\
\text { deviation) }\end{array}$} & Most & $\begin{array}{c}10 \mathrm{~mm} \text {-thick PDMS } \\
(8.6048 \pm 2.2481)\end{array}$ & $\begin{array}{c}10 \mathrm{~mm} \text {-thick PDMS } \\
(8.7129 \pm 2.1087)\end{array}$ & $\begin{array}{c}10 \mathrm{~mm} \text {-thick PDMS } \\
(8.5968 \pm 2.3853)\end{array}$ & $\begin{array}{c}3.4 \mathrm{~mm} \text {-thick Dragon skin } \\
(8.1782 \pm 2.4673)\end{array}$ \\
\cline { 2 - 6 } & Least & $\begin{array}{c}10 \mathrm{~mm} \text {-thick Ecoflex } \\
(3.8468 \pm 2.7141)\end{array}$ & $\begin{array}{c}7 \mathrm{~mm} \text {-thick Ecoflex } \\
(3.6436 \pm 2.5439)\end{array}$ & $\begin{array}{c}7 \mathrm{~mm} \text {-thick Ecoflex } \\
(2.8871 \pm 2.2782)\end{array}$ & $\begin{array}{c}7 \mathrm{~mm} \text {-thick Ecoflex } \\
(2.5050 \pm 1.8741)\end{array}$ \\
\hline $\begin{array}{c}\text { Stickiness } \\
\text { (survey results } \\
\text { with standard } \\
\text { deviation) }\end{array}$ & Most & $\begin{array}{c}7 \mathrm{~mm} \text {-thick Ecoflex } \\
(3.8455 \pm 2.7342)\end{array}$ & $\begin{array}{c}7 \mathrm{~mm} \text {-thick Ecoflex } \\
(3.2574 \pm 2.4926)\end{array}$ & $\begin{array}{c}7 \mathrm{~mm} \text {-thick Ecoflex } \\
(4.1452 \pm 2.6555)\end{array}$ & $\begin{array}{c}7 \mathrm{~mm} \text {-thick Ecoflex } \\
(3.6436 \pm 2.5162)\end{array}$ \\
\cline { 2 - 7 } & Least & $\begin{array}{c}10 \mathrm{~mm} \text {-thick PDMS } \\
(8.6129 \pm 2.3982)\end{array}$ & $\begin{array}{c}10 \mathrm{~mm} \text {-thick PDMS } \\
(8.5149 \pm 2.2610)\end{array}$ & $\begin{array}{c}10 \mathrm{~mm} \text {-thick PDMS } \\
(8.7984 \pm 2.1260)\end{array}$ & $\begin{array}{c}10 \mathrm{~mm} \text {-thick PDMS } \\
(8.1584 \pm 2.4565)\end{array}$ \\
\hline $\begin{array}{c}\text { Familiarity } \\
\text { (survey results } \\
\text { with standard } \\
\text { deviation) }\end{array}$ & Most & $\begin{array}{c}7 \mathrm{~mm} \text {-thick PDMS } \\
(6.6855 \pm 2.2609)\end{array}$ & $\begin{array}{c}7 \mathrm{~mm} \text {-thick PDMS } \\
(6.4752 \pm 2.2565)\end{array}$ & $\begin{array}{c}10 \mathrm{~mm} \text {-thick Dragon skin } \\
(6.9597 \pm 2.1391)\end{array}$ & $\begin{array}{c}3.4 \mathrm{~mm} \text {-thick PDMS } \\
(6.6733 \pm 2.1914)\end{array}$ \\
\cline { 2 - 7 } & Least & $\begin{array}{c}3.4 \mathrm{~mm} \text {-thick Ecoflex } \\
(5.7177 \pm 2.2543)\end{array}$ & $\begin{array}{c}7 \mathrm{~mm} \text {-thick Ecoflex } \\
(5.2475 \pm 2.5393)\end{array}$ & $\begin{array}{c}3.4 \mathrm{~mm} \text {-thick Ecoflex } \\
(6.0806 \pm 2.1924)\end{array}$ & $\begin{array}{c}3.4 \mathrm{~mm} \text {-thick Ecoflex } \\
(5.6535 \pm 2.3683)\end{array}$ \\
\hline $\begin{array}{c}\text { Preference } \\
\text { (survey results } \\
\text { with standard } \\
\text { deviation) }\end{array}$ & Most & $\begin{array}{c}7 \mathrm{~mm} \text {-thick Dragon skin } \\
(6.8548 \pm 2.2038)\end{array}$ & $\begin{array}{c}10 \mathrm{~mm} \text {-thick PDMS } \\
(6.5446 \pm 2.3728)\end{array}$ & $\begin{array}{c}10 \mathrm{~mm} \text {-thick Ecoflex } \\
(7.2823 \pm 2.9149)\end{array}$ & $\begin{array}{c}10 \mathrm{~mm} \text { Dragon-thick skin } \\
(6.9010 \pm 2.2427)\end{array}$ \\
\cline { 2 - 7 } & Least & $\begin{array}{c}3.4 \mathrm{~mm} \text {-thick Ecoflex } \\
(5.6452 \pm 2.0960)\end{array}$ & $\begin{array}{c}3.4 \mathrm{~mm} \text {-thick Ecoflex } \\
(4.7129 \pm 2.3252)\end{array}$ & $\begin{array}{c}3.4 \mathrm{~mm} \text {-thick Ecoflex } \\
(6.0000 \pm 2.2378)\end{array}$ & $\begin{array}{c}7 \mathrm{~mm} \text {-thick Ecoflex } \\
(5.5842 \pm 3.1599)\end{array}$ \\
\hline
\end{tabular}

Table 2. Material preferences for males and females on the shoulder tactile sensation

\begin{tabular}{|c|c|c|c|c|}
\hline & \multicolumn{2}{|c|}{ Male } & \multicolumn{2}{c|}{ Female } \\
\cline { 2 - 5 } & $\begin{array}{c}\text { Standardized } \\
\text { coefficient }\end{array}$ & C.R. (p-value) & $\begin{array}{c}\text { Standardized } \\
\text { coefficient }\end{array}$ & C.R. (p-value) \\
\hline Stiffness $\rightarrow$ Preference & -.103 & $-3.241(.001)$ & -.049 & $-1.432(.152)$ \\
\hline Stickiness $\rightarrow$ Preference & .220 & $6.816(.001)$ & .245 & $7.044(.001)$ \\
\hline Familiarity $\rightarrow$ Preference & .521 & $20.778(.001)$ & .465 & $16.422(.001)$ \\
\hline
\end{tabular}

Finally, physical properties, such as contact angle and compressive creep test, were evaluated for each material in order to relate preference to materials' mechanical properties. The contact angle test is an indirect way of describing perception to adhesion, while the compressive creep test was conducted to measure the degree of stiffness (Wu et al., 2013).

This study is suited to an appropriate technology in that it improves the safety of workers laboring in the same space as a cooperative robot using inexpensive polymer materials, to protect the human while solving environmental problems which are hazardous and expensive processes.

\section{Materials and Methods}

\section{Sample preparation}

Sample fabrication is carried out through following process. For Dragon skin and Ecoflex, parts labeled A and B were mixed at a 1:1 weight ratio. After keeping the mixture at room temperature for 24 hours, samples were cured at $80^{\circ} \mathrm{C}$ for 2 hours and at $100^{\circ} \mathrm{C}$ for 1 hour. PDMS was manufactured by mixing Sylgard $184 \mathrm{~A}$ and $\mathrm{B}$ at a weight ratio of 10:1 followed by curing at $100^{\circ} \mathrm{C}$ for 45 minutes. Square samples $(14 \mathrm{~cm}$ $\times 14 \mathrm{~cm}$ ) of each material were prepared with three types of thicknesses $(3.4 \mathrm{~mm}, 7 \mathrm{~mm}$, and $10 \mathrm{~mm})$ for the preference survey. The samples used to determine the mechanical properties of the materials were prepared according to American Society for Testing and Materials (ASTM) standards. Samples intended for contact angle test were manufactured in accordance with ASTM D 5946, and samples for compressive creep test were fabricated in accordance with ASTM D 695.

\section{Preference survey}

9 samples shown in Figure 2(a) were prepared to be attached to the wall at shoulder height and the participants 
touched each sample with elbows and shoulders as shown in Figure 2(b) to answer the questionnaire. The samples were arranged randomly for fairness. The survey was conducted with 225 between the ages of 20 and 30. Participants' consent forms were obtained before the experiment. Participation was a voluntary one. There was no benefit or harm originated from this experiment.

All questionnaires responded to the experiment for the same time period and responded to the questionnaire after contacting each sample for about 3 seconds in duration. In addition, between participants, gap of 1-2 minutes was given to contact the next sample after contacting one. The respondents rated their experiences on 4 features (stiffness, stickiness, familiarity, and preference) using a 11-point Likertscale, as respondents make contact with three different materials of three different thicknesses, at their elbow and shoulder, respectively. The results of the preference survey were analyzed using frequency analysis, comparison of means (t-test) (Choi et al., 2019), multiple regression (MR) (Mark and Goldberg, 1988), and structural model analysis, to investigate the differences between genders as well as how significant those differences are in terms of statistical point of view.

\section{Results and Discussion}

\section{Analysis of preference survey}

In this section, the preference survey results on shoulder and elbow touch was analyzed by gender, respectively as Table 1 summarizes the preference survey result showing the maximum and minimum scores for each factor by gender as well as body parts.

\subsection{Survey results for shoulder tactile sensation by gender}

Table 1 shows the survey results for shoulder and elbow tactile sensation in terms of stiffness, stickiness, familiarity, and preference. Regarding shoulder tactile sensation, $7 \mathrm{~mm}$ thick Ecoflex was rated as the softest material, while $10 \mathrm{~mm}$ thick PDMS was rated as the hardest material.

Furthermore, $7 \mathrm{~mm}$-thick Ecoflex was also rated as the stickiest material, while $10 \mathrm{~mm}$-thick PDMS was rated as the least sticky material. Moreover, $7 \mathrm{~mm}$-thick PDMS was rated as the most familiar material, while $3.4 \mathrm{~mm}$-thick and $7 \mathrm{~mm}$ thick Ecoflex were rated as the least familiar materials. These results of stiffness, stickiness and familiarity were common for both male and female. However, the most preferred material was found to be different for male and female; male preferred $7 \mathrm{~mm}$-thick dragon skin while female preferred $10 \mathrm{~mm}$-thick PDMS

To figure out any differences in each factor by gender, $\mathrm{t}$ test was conducted for the shoulder tactile sensation. As shown in Table S1 and S2, the difference for each factors by gender was obtained as a result of t-test and Levene's test. According to Levene's test, equal variances for stiffness, stickiness, familiarity and preference through the value of $\mathrm{p}$ (significance) is assumed to be valid so that the values of the test statistic $t$, degree of freedom (df) and the observation factor $\mathrm{p}$ (significance), showed significant differences in stickiness, familiarity, and preference, except for stiffness by gender. Therefore, it was confirmed that both male and female showed similar trend for stiffness, while showing different trends for stickiness, familiarity and preference.

Finally, material ratings were compared using multiple regression analysis by gender in order to identify how sensitive male (or female) is to the senses, such as stiffness, stickiness and familiarity. As a result, it was found that female is more sensitive than male in terms of stickiness during the shoulder touch (Table 2). Also, it was found that male is more sensitive than female in terms of familiarity during the shoulder touch. That is, male is affected more by the familiarity while the preference for female is affected by the familiarity.

Table 3. Material preferences of males and females for the elbow touch

\begin{tabular}{|c|c|c|c|c|}
\hline & \multicolumn{2}{|c|}{ Male } & \multicolumn{2}{c|}{ Female } \\
\cline { 2 - 5 } & $\begin{array}{c}\text { Standardized } \\
\text { coefficient }\end{array}$ & C.R. (p-value) & $\begin{array}{c}\text { Standardized } \\
\text { coefficient }\end{array}$ & C.R. (p-value) \\
\hline Stiffness $\rightarrow$ Preference & -.275 & $-8.634(.001)$ & -.054 & $-1.576(.115)$ \\
\hline Stickiness $\rightarrow$ Preference & .270 & $8.367(.001)$ & .185 & $5.214(.001)$ \\
\hline Familiarity $\rightarrow$ Preference & .519 & $21.098(.001)$ & .481 & $16.693(.001)$ \\
\hline
\end{tabular}




\subsection{Survey results for elbow touch by gender}

As Table 1 shows survey results for elbow touch, $7 \mathrm{~mm}$ thick Ecoflex was rated as the softest material for both male and female, while $10 \mathrm{~mm}$-thick PDMS and $3.4 \mathrm{~mm}$-thick Dragon skin were rated as the hardest material for male and female, respectively. Furthermore, $7 \mathrm{~mm}$-thick Ecoflex was also rated as the stickiest material, while $10 \mathrm{~mm}$-thick PDMS was rated as the least sticky material for both male and female. Moreover, $3.4 \mathrm{~mm}$-thick Ecoflex was rated as the least familiar material for both male and female, while $10 \mathrm{~mm}$-thick Dragon skin and $3.4 \mathrm{~mm}$-thick PDMS were rated as the most familiar material for male and female, respectively. As a result, it was found that male and female showed significantly different senses for the elbow touch, resulting in the different preference results for the materials.

To figure out the difference for each factor by gender, t-test was conducted for the elbow touch. As shown in Table S3 and S4, the difference among each factor by gender was obtained as a result of t-test and Levene's test. According to Levene's test, equal variances for stiffness, stickiness, familiarity and preference through the value of $\mathrm{p}$ (significance) is assumed to be valid so that the values of the test statistic $t$ and degree of freedom (df) and the observation factor $\mathrm{p}$ (significance) showed significant differences in stiffness, familiarity, and preference, except for stickiness, by gender. Therefore, it was confirmed that both male and female showed similar senses for stickiness, while showing difference responses for stiffness, familiarity, and preference.
In addition, material ratings were compared using multiple regression analysis by gender to identify how sensitive male (or female) is to stiffness, stickiness, and familiarity. As a result, it was found that male is more sensitive to both stickiness and familiarity than females do during the elbow touch. That is, the preference for the male is influenced more by the stickiness and familiarity than the preference for female being affected by those factors.

\subsection{Correlation analysis of each factor to material pre- ference}

The contributions of stiffness, stickiness and familiarity to the preferences were analyzed by multiple regression method as shown in Tables 4 and 5. The Pearson correlation was found to be less than 0.7 , indicating meaningful results for multiple regression analysis since the assumption of multicollinearity exists.

According to the multiple regression analysis for the shoulder touch, the independent variables including stiffness, stickiness and familiarity were found to predict its preference by $56.7 \%$ as shown in Tables S5, S6 and S7. The variance (SSR) described by the regression model is 3780.176 , the undated variance is 7977.708 , and the overall significance of the regression model is $\mathrm{F}(32021)=319.236$, with $\mathrm{p}<.001$, yielding a significant result. This is useful data describing its preferences. Based on the analysis, the multiple regression model can be expressed by the non-standardized coefficients (B), as follows:

Table 4. Correlation analysis for the shoulder touch

(**the correlation coefficient is significant at the level of $\mathrm{p}<0.01$ )

\begin{tabular}{|c|c|c|c|c|c|}
\hline & & Stiffness & Stickiness & Familiarity & Preference \\
\hline \multirow{3}{*}{ Stiffness } & Pearson correlation & 1 & $.623 * *$ & $.101^{* *}$ & .022 \\
\hline & Sig.(2-tailed) & & .000 & .000 & .320 \\
\hline & $\mathrm{N}$ & 2025 & 2025 & 2025 & 2025 \\
\hline \multirow{3}{*}{ Stickiness } & Pearson correlation & $.623 * *$ & 1 & $.214^{* *}$ & $.226^{* *}$ \\
\hline & Sig.(2-tailed) & .000 & & .000 & .000 \\
\hline & $\mathrm{N}$ & 2025 & 2025 & 2025 & 2025 \\
\hline \multirow{3}{*}{ Familiarity } & Pearson correlation & $.101^{* *}$ & $.214 * *$ & 1 & $.536^{* *}$ \\
\hline & Sig.(2-tailed) & .000 & .000 & & .000 \\
\hline & $\mathrm{N}$ & 2025 & 2025 & 2025 & 2025 \\
\hline \multirow{3}{*}{ Preference } & Pearson correlation & .022 & $.226 * *$ & $.536 * *$ & 1 \\
\hline & Sig.(2-tailed) & .320 & .000 & .000 & \\
\hline & $\mathrm{N}$ & 2025 & 2025 & 2025 & 2025 \\
\hline
\end{tabular}


Table 5. Correlation analysis for the elbow touch

(**the correlation coefficient is significant at the level of $\mathrm{p}<0.01$ )

\begin{tabular}{|c|c|c|c|c|c|}
\hline & & Stiffness & Stickiness & Familiarity & Preference \\
\hline \multirow{3}{*}{ Stiffness } & Pearson correlation & 1 & $.626^{* *}$ & $.152 * *$ & $.148^{* *}$ \\
\hline & Sig.(2-tailed) & & .000 & .000 & .000 \\
\hline & $\mathrm{N}$ & 2025 & 2025 & 2025 & 2025 \\
\hline \multirow{3}{*}{ Stickiness } & Pearson correlation & $.626^{* *}$ & 1 & $.230^{* *}$ & $.305 * *$ \\
\hline & Sig.(2-tailed) & .000 & & .000 & .000 \\
\hline & $\mathrm{N}$ & 2025 & 2025 & 2025 & 2025 \\
\hline \multirow{3}{*}{ Familiarity } & Pearson correlation & $.152 * *$ & $.230 * *$ & 1 & $.532 * *$ \\
\hline & Sig.(2-tailed) & .000 & .000 & & .000 \\
\hline & $\mathrm{N}$ & 2025 & 2025 & 2025 & 2025 \\
\hline \multirow{3}{*}{ Preference } & Pearson correlation & $.148^{* *}$ & $.305^{* *}$ & $.532 * *$ & 1 \\
\hline & Sig.(2-tailed) & .000 & .000 & .000 & \\
\hline & $\mathrm{N}$ & 2025 & 2025 & 2025 & 2025 \\
\hline
\end{tabular}

$$
Y=2.427-0.061 X_{1}+0.186 X_{2}+0.493 X_{3}
$$

In the equation (1), $Y$ is preference while $X_{1}$ is stiffness, $X_{2}$ is stickiness and $X_{3}$ is familiarity.

Therefore, equation (1) confirms that the preference for shoulder touch is highly related to familiarity first and then stickiness.

Based on the multiple regression analysis for the elbow touch, the independent variables including stiffness, stickiness and familiarity were found to predict its preference by $56.3 \%$ as shown in Table S8, S9 and S10. The variance (SSR) described by the regression model is 3928.328 , the undated variance is 8456.605 , while the overall significance of the regression model is $\mathrm{F}(32021)=313.017$, with $\mathrm{p}<.001$ yielding a significant result. Again, this is a useful data in describing preferences. According to the analysis, the multiple regression model is expressed by the non-standardized coefficients(B), as follows:

$$
Y=2.738-0.127 X_{1}+0.181 X_{2}+0.53 X_{3}
$$

In the equation (2), $Y$ is preference while $X_{1}$ is stiffness, $X_{2}$ is stickiness and $X_{3}$ is familiarity.

Equation (2) confirms that the preference for elbow touch is again highly related to familiarity while it is equally related to both stiffness and stickiness.

Therefore, we derived a mathematical formula for genderbased robot skin material preferences based on stiffness, stickiness and familiarity.

\section{Evaluation of Mechanical properties}

Based on the above results, stiffness and stickiness influenced material preference. These factors were also analyzed in terms of mechanical properties, as they relate to the preference of the gender. (a)

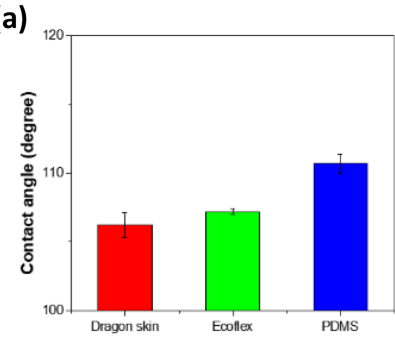

(b)

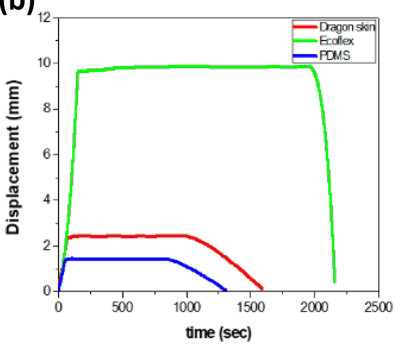

Figure 3. (a) Contact angle measurement result and (b) displacement-time curves of dragon skin, Ecoflex, and PDMS, respectively

The contact angle test was conducted in order to compare the stickiness of materials. Contact angle was measured by dropping $0.003 \sim 0.004 \mathrm{~mL}$ of distilled water onto the specimen using the equipment Phoenix 300 Tough (S.E.O.).

As a result, the contact angles for Dragon skin, Ecoflex and PDMS were measured to be $106.2^{\circ}, 107.2^{\circ}$, and $110.7^{\circ}$, respectively (Figure 3(a)). These results confirmed that the contact angle and stickiness are inversely related as the section 3.1 explains how. Furthermore, PDMS was considered the least sticky material but exhibited the largest contact angle. Ecoflex and Dragon skin yielded smaller contact angles and 
were both considered stickier than PDMS. Thus, our contact angle measurements are consistent with the survey result and can therefore be used as indicators of stickiness.

Moreover, compressive creep test was performed on a Universal Testing Machine (UTM), with a load of $15 \pm 1 \mathrm{~N}$ maintained for 30 minutes followed by a 15 -minute recovery period. This indicates how much a specimen has been deformed under a given load. Greater strain under the given load indicates less stiffness. The strain (\%) was calculated shown below:

$$
\text { strain }(\%)=\left(\frac{t_{i}-t_{f}}{t_{i}}\right) \times 100
$$

where $t_{i}$ and $t_{f}$ are the sample thicknesses before and after the test, respectively. As shown in Figure 3(b), the greatest displacement after the load application was observed with Ecoflex. This is consistent with the results of our preference survey, which indicated that Ecoflex is the softest material. Similarly, PDMS, which was rated as the stiffest material in our preference survey, showed the lowest rate of change under an applied load. These data confirmed that the results of compressive creep tests can serve as reliable indicators of perceived stiffness. (a)

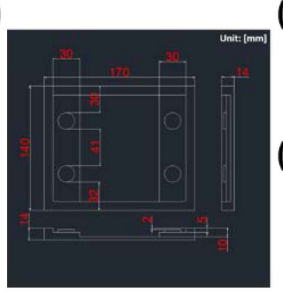

(b)

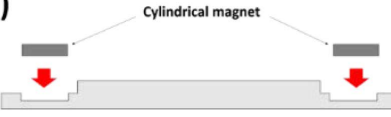

(c)

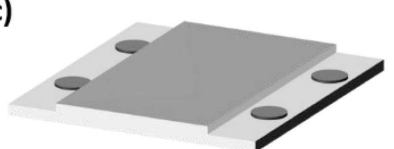

Figure 4. (a) Mold design, (b) Schematic of the sample cross section, and (c) completed sample image

\section{Application of the developed skin}

For the recently developed cooperative robots, coding work for collision prevention or an automatic stop function in case of collision are applied, but this function can not be incorporated to the existing cooperative robots. Moreover, minor collision to be in touch with robot's cold metal skin can cause workers emotional discomforts. To overcome this problem, cooperative robot used the polymer robot skin to protect human as shown in Figure 5. The sample was prepared using a mold as shown in Figure 4(a), and a cylindrical magnet was attached to the recessed part in the form of Figure 4(c) for (a)

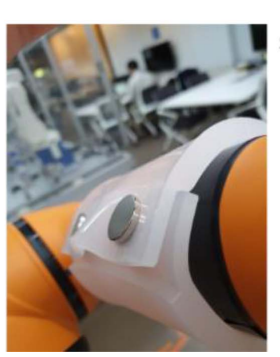

(b)

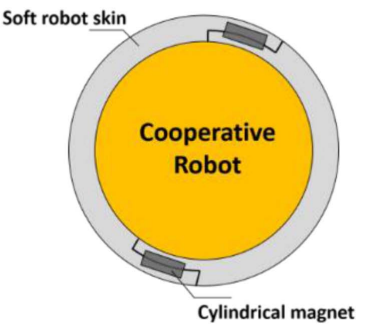

Figure 5. (a) Actual sample applied image, (b) schematic of sample application

the function of attach/detach. The samples can be attached in a form that surrounds the surface of the robot. Here, since the sample magnet can be easily detached, the skin can be easily separated from the robot as shown in Figure 5.

\section{Conclusions}

In this study, three polymer materials such as Dragon skin, Ecoflex and PDMS, were evaluated in terms of gender-based preference for the application of robot skins in relation to different body parts in contact with the robot. As a result, the preference survey showed that the material preference indeed varied by respondent gender with the point of contact (elbow or shoulder). Moreover, male and female showed different tendency of how much each factor influenced the preference. For shoulder, male was more responsive to stickiness than female did, whereas in the case of elbow, female was more responsive to the stickiness than male did. Moreover, contact angle and compressive creep test were conducted to establish the relationship between the preferences and the mechanical properties. As a result, perceived stickiness was inversely correlated to contact angle, while stiffness was directly correlated with strain rate which is measured by compressive creep test. These data could be useful when selecting the preference materials to be used for gender-based indicator in the manufacture of cooperative robot skins.

\section{Acknowledgements}

This research was supported by Support Program for Women in Science, Engineering and Technology through the Center for Women In Science, Engineering and Technology (WISET) funded by the Ministry of Science and ICT (No. 
WISET202003GI01). The authors would like to thank KESTONECG for performing the statistical analysis.

\section{Conflict of Interest}

The authors declare that they have no conflict of interest.

\section{References}

Berthiaume, M. D. (1999). Silicones in Cosmetics, in: Principles of Polymer Science and Technology in Cosmetics and Personal Care, Marcel Dekker, New York, pp. 275-324.

Bongaerts, J. H. H., Fourtouni, K., and Stokes, J. R. (2007). Softtribology: Lubrication in a Compliant PDMS-PDMS Contact, Tribology International, 40, pp. 1531-1542.

Choi, D., Kim, H., Son, M., Kim, H., Lee, H. C., and Lee, C. S. (2019). Fabrication of a Kinetically Sprayed CuO Ultra-thin Film to Evaluate CO Gas Sensing Parameters, New Journal of Chemistry, 43, pp. 7814-7821.

Gerde, J. A., Hammond, E. G., and White, P. J. (2011). Influence of Polydimethylsiloxane on the Degradation of Soybean Oil at Frying Temperature, Journal of the American Oil Chemists' Society, 88, 1573.

Goddard, E. D. and Gruber, J. V. (1999). Principles of Polymer Science and Technology in Cosmetics and Personal Care. CRC Press.

Jeong, J.-Y., Lee, E. J., Park, H., and Chu, W.-S. (2020). Exo-Skeletal Flexible Structure for Communal Touch Device, Journal of Appropriate Technology, 6(2), pp. 219-225.

Kim, D.-R., Jang, K.-H., Chu, W.-S., Choi, D., Lee, W. I., Lee, C. S., and Ahn, S.-H. (2019). Preference for Case Materials in Smart Devices: A Comparative Study in Korea, USA, and Tanzania. International Journal of Precision Engineering and Manufacturing, 20, pp. 749-767.

Kim, J., Alspach, A., and Yamane, K. (2015). 3D Printed Soft
Skin for Safe Human-Robot Interaction, In 2015 IEEE/RSJ International Conference on Intelligent Robots and Systems (IROS), pp. 2419-2425.

Lin, C.-H., Yeh, Y.-H., Lin, W.-C., and Yang, M.-C. (2014). Novel Silicone Hydrogel based on PDMS and PEGMA for Contact Lens Application, Colloids and Surfaces B: Biointerfaces, 123, pp. 986-994.

Mark, J. and Goldberg, M. A. (1988). Multiple Regression Analysis and Mass Assessment: A Review of the Issues, Appraisal Journal, 56, p. 89.

Pang, G., Deng, J., Wang, F., Zhang, J., Pang, Z., and Yang, G. (2018). Development of Flexible Robot Skin for Safe and Natural Human-Robot Collaboration, Micromachines, 9(11), 576.

Roos, P. A. (1985). Gender and work: A comparative analysis of industrial societies, SUNY Press.

Shimizu, R. and Nonomura, Y. (2018). Preparation of Artificial Skin that Mimics Human Skin Surface and Mechanical Properties, Journal of Oleo Science, 67(1), pp. 47-54.

Shirado, H., Nonomura, Y., and Maeno, T. (2006). Realization of Human Skin-like Texture by Emulating Surface Shape Pattern and Elastic Structure, Symposium on Haptic Interfaces for Virtual Environment and Teleoperator Systems 2006, IEEE, Alexandria, Virginia, USA.

Taisuke, S., Hiroyasu, I., and Sugano, S. (2008). Shock Absorbing Skin Design for Human-Symbiotic Robot at the Worst Case Collision, In Humanoids 2008 - 8th IEEE-RAS International Conference on Humanoid Robots, pp. 481-486.

Wu, J., Xia, J., Lei, W., and Wang, B.-P. (2013). Advanced Understanding of Stickiness on Superhydrophobic Surfaces, Scientific Reports, 3, pp. 1-4.

Yamashita, Y., Ishihara, H., Ikeda, T., and Asada, M. (2019). Investigation of Causal Relationship Between Touch Sensations of Robots and Personality Impressions by Path Analysis, International Journal of Social Robotics, 11, pp. 141-150. 


\title{
Evaluation of materials related to Gender-Preferences for the application of Cooperative Robot Skin
}

\author{
Minhee Son, Dongwon Shin, and Caroline Sunyong Lee
}

Department of Materials and Chemical engineering, Hanyang University, Ansan-si, Gyeonggi-do, 15588, Republic of Korea

(*Corresponding Author E-mail: sunyonglee@hanyang.ac.kr)

Table S1. Scores for shoulder touch by gender

\begin{tabular}{|c|c|c|c|c|c|}
\hline & & \multicolumn{2}{|c|}{ Male } & \multicolumn{2}{|c|}{ Female } \\
\hline & & Mean & S.D & Mean & S.D \\
\hline \multirow{9}{*}{ Stiffness } & $3.4 \mathrm{~mm}$ Ecoflex & 5.8387 & 2.7390 & 4.7624 & 2.8465 \\
\hline & 7 mm PDMS & 7.3226 & 2.5135 & 7.6238 & 2.4893 \\
\hline & $10 \mathrm{~mm}$ Dragon-skin & 7.7903 & 2.4899 & 7.7228 & 2.4335 \\
\hline & $3.4 \mathrm{~mm}$ PDMS & 8.1290 & 2.2630 & 8.2079 & 2.2904 \\
\hline & $7 \mathrm{~mm}$ Ecoflex & 3.9597 & 2.4607 & 3.6436 & 2.5439 \\
\hline & $3.4 \mathrm{~mm}$ Dragon-skin & 8.0806 & 2.3079 & 8.1386 & 2.4496 \\
\hline & $10 \mathrm{~mm}$ Ecoflex & 3.8468 & 2.8141 & 4.7822 & 3.1483 \\
\hline & 7 mm Dragon-skin & 7.7419 & 2.4820 & 6.7327 & 2.8805 \\
\hline & $10 \mathrm{~mm}$ PDMS & 8.6048 & 2.2481 & 8.7129 & 2.1087 \\
\hline \multirow{9}{*}{ Stickiness } & $3.4 \mathrm{~mm}$ Ecoflex & 4.9597 & 2.9256 & 3.8812 & 2.6731 \\
\hline & 7 mm PDMS & 7.0323 & 2.8368 & 6.8515 & 2.6809 \\
\hline & $10 \mathrm{~mm}$ Dragon-skin & 7.7419 & 2.6955 & 7.3366 & 2.7650 \\
\hline & $3.4 \mathrm{~mm}$ PDMS & 8.0081 & 2.5327 & 7.8812 & 2.6468 \\
\hline & 7 mm Ecoflex & 3.8455 & 2.7342 & 3.2574 & 2.4926 \\
\hline & $3.4 \mathrm{~mm}$ Dragon-skin & 7.3952 & 2.7343 & 7.0099 & 2.6019 \\
\hline & $10 \mathrm{~mm}$ Ecoflex & 4.7661 & 2.5980 & 4.6832 & 2.7565 \\
\hline & $7 \mathrm{~mm}$ Dragon-skin & 7.9194 & 2.4180 & 7.0990 & 2.8407 \\
\hline & $10 \mathrm{~mm}$ PDMS & 8.6129 & 2.3982 & 8.5149 & 2.2610 \\
\hline \multirow{9}{*}{ Familiarity } & $3.4 \mathrm{~mm}$ Ecoflex & 5.7177 & 2.2543 & 5.2772 & 2.5538 \\
\hline & 7 mm PDMS & 6.6855 & 2.2609 & 6.4752 & 2.2565 \\
\hline & $10 \mathrm{~mm}$ Dragon-skin & 6.4597 & 2.3422 & 6.4356 & 2.3681 \\
\hline & $3.4 \mathrm{~mm}$ PDMS & 6.4032 & 2.4258 & 6.3861 & 2.4123 \\
\hline & $7 \mathrm{~mm}$ Ecoflex & 5.7903 & 2.5702 & 5.2475 & 2.5393 \\
\hline & $3.4 \mathrm{~mm}$ Dragon-skin & 6.1935 & 2.1286 & 5.7327 & 2.2754 \\
\hline & $10 \mathrm{~mm}$ Ecoflex & 6.1210 & 2.3636 & 6.1188 & 2.4465 \\
\hline & 7 mm Dragon-skin & 6.6210 & 2.1511 & 6.2178 & 2.1936 \\
\hline & $10 \mathrm{~mm}$ PDMS & 6.5161 & 2.4444 & 6.3465 & 2.4512 \\
\hline \multirow{9}{*}{ Preference } & $3.4 \mathrm{~mm}$ Ecoflex & 5.6452 & 2.0960 & 4.7129 & 2.3252 \\
\hline & 7 mm PDMS & 6.6210 & 2.0820 & 6.3663 & 2.1758 \\
\hline & $10 \mathrm{~mm}$ Dragon-skin & 6.6774 & 2.1472 & 6.4554 & 2.1048 \\
\hline & $3.4 \mathrm{~mm}$ PDMS & 6.7419 & 2.3885 & 6.4356 & 2.2821 \\
\hline & 7 mm Ecoflex & 6.0000 & 2.8513 & 4.7525 & 2.8085 \\
\hline & $3.4 \mathrm{~mm}$ Dragon-skin & 6.5000 & 2.1621 & 6.0792 & 2.1757 \\
\hline & $10 \mathrm{~mm}$ Ecoflex & 6.7984 & 2.5213 & 5.9010 & 2.5397 \\
\hline & $7 \mathrm{~mm}$ Dragon-skin & 6.8548 & 2.2038 & 6.3861 & 2.2802 \\
\hline & $10 \mathrm{~mm}$ PDMS & 6.7339 & 2.4696 & 6.5446 & 2.3728 \\
\hline
\end{tabular}


Table S2. Scores for elbow touch by gender

\begin{tabular}{|c|c|c|c|c|c|}
\hline & & \multicolumn{2}{|c|}{ Male } & \multicolumn{2}{|c|}{ Female } \\
\hline & & Mean & S.D & Mean & S.D \\
\hline \multirow{9}{*}{ Stiffness } & $3.4 \mathrm{~mm}$ Ecoflex & 5.4194 & 2.6659 & 4.4851 & 2.4315 \\
\hline & $7 \mathrm{~mm}$ PDMS & 7.5968 & 2.4090 & 7.7525 & 2.1652 \\
\hline & $10 \mathrm{~mm}$ Dragon-skin & 7.4194 & 2.6659 & 7.2079 & 2.4670 \\
\hline & $3.4 \mathrm{~mm}$ PDMS & 8.5726 & 2.2638 & 8.4158 & 2.2815 \\
\hline & $7 \mathrm{~mm}$ Ecoflex & 2.8871 & 2.2782 & 2.5050 & 1.8741 \\
\hline & $3.4 \mathrm{~mm}$ Dragon-skin & 8.4919 & 2.3736 & 8.1782 & 2.4673 \\
\hline & $10 \mathrm{~mm}$ Ecoflex & 2.9274 & 2.5919 & 3.6634 & 3.0701 \\
\hline & $7 \mathrm{~mm}$ Dragon-skin & 8.1694 & 2.3641 & 6.6040 & 3.2406 \\
\hline & $10 \mathrm{~mm}$ PDMS & 8.5968 & 2.3853 & 8.0297 & 2.6247 \\
\hline \multirow{9}{*}{ Stickiness } & $3.4 \mathrm{~mm}$ Ecoflex & 5.2984 & 2.7878 & 4.3960 & 2.6384 \\
\hline & 7 mm PDMS & 6.9516 & 2.8308 & 7.7327 & 2.4326 \\
\hline & $10 \mathrm{~mm}$ Dragon-skin & 7.9919 & 2.4742 & 7.5644 & 2.4715 \\
\hline & 3.4 mm PDMS & 8.3548 & 2.3930 & 8.7129 & 2.0704 \\
\hline & 7 mm Ecoflex & 4.1452 & 2.6555 & 3.6436 & 2.5162 \\
\hline & $3.4 \mathrm{~mm}$ Dragon-skin & 7.3952 & 2.6954 & 7.4455 & 2.5158 \\
\hline & $10 \mathrm{~mm}$ Ecoflex & 4.5565 & 2.7624 & 4.8812 & 2.8435 \\
\hline & $7 \mathrm{~mm}$ Dragon-skin & 8.3952 & 2.2372 & 7.1386 & 2.8496 \\
\hline & $10 \mathrm{~mm}$ PDMS & 8.7984 & 2.1260 & 8.1584 & 2.4565 \\
\hline \multirow{9}{*}{ Familiarity } & $3.4 \mathrm{~mm}$ Ecoflex & 6.0806 & 2.1924 & 5.6535 & 2.3683 \\
\hline & $7 \mathrm{~mm}$ PDMS & 6.5645 & 2.2640 & 6.4851 & 2.2522 \\
\hline & $10 \mathrm{~mm}$ Dragon-skin & 6.9597 & 2.1391 & 6.5545 & 2.2604 \\
\hline & $3.4 \mathrm{~mm}$ PDMS & 6.7177 & 2.1885 & 6.6733 & 2.1914 \\
\hline & $7 \mathrm{~mm}$ Ecoflex & 6.2016 & 2.6194 & 5.7624 & 2.6501 \\
\hline & $3.4 \mathrm{~mm}$ Dragon-skin & 6.2823 & 2.2580 & 6.1980 & 2.3023 \\
\hline & $10 \mathrm{~mm}$ Ecoflex & 6.4435 & 2.5576 & 6.0396 & 2.4328 \\
\hline & $7 \mathrm{~mm}$ Dragon-skin & 6.7177 & 2.3219 & 6.5050 & 2.4274 \\
\hline & $10 \mathrm{~mm}$ PDMS & 6.7984 & 2.3058 & 6.4950 & 2.3901 \\
\hline \multirow{9}{*}{ Preference } & $3.4 \mathrm{~mm}$ Ecoflex & 6.0000 & 2.2378 & 5.6832 & 2.2800 \\
\hline & $7 \mathrm{~mm}$ PDMS & 6.2984 & 2.3442 & 6.4554 & 2.1978 \\
\hline & $10 \mathrm{~mm}$ Dragon-skin & 7.1129 & 2.0331 & 6.9010 & 2.2427 \\
\hline & $3.4 \mathrm{~mm}$ PDMS & 6.4839 & 2.2934 & 6.3960 & 2.3327 \\
\hline & $7 \mathrm{~mm}$ Ecoflex & 6.8065 & 3.0462 & 5.5842 & 3.1599 \\
\hline & $3.4 \mathrm{~mm}$ Dragon-skin & 6.4194 & 2.3097 & 6.4752 & 2.3349 \\
\hline & $10 \mathrm{~mm}$ Ecoflex & 7.2823 & 2.9149 & 6.2376 & 2.7428 \\
\hline & $7 \mathrm{~mm}$ Dragon-skin & 6.7742 & 2.1407 & 6.6535 & 2.4225 \\
\hline & $10 \mathrm{~mm}$ PDMS & 6.9597 & 2.4409 & 6.7822 & 2.1799 \\
\hline
\end{tabular}


Table S3. The independent sample t-test results of shoulder tactile sensation by gender

\begin{tabular}{|c|c|c|c|c|c|}
\hline & Gender & $\mathrm{N}$ & Mean & Standard deviation & Standard error \\
\hline \multirow{3}{*}{ Stiffness } & Male & 1116 & 6.8127 & 3.0046 & .0899 \\
\cline { 2 - 6 } & Female & 909 & 6.7030 & 3.1120 & .1032 \\
\hline \multirow{3}{*}{ Stickiness } & Male & 1116 & 6.6998 & 3.0999 & .0928 \\
\cline { 2 - 6 } & Female & 909 & 6.2794 & 3.1600 & .1048 \\
\hline \multirow{2}{*}{ Familiarity } & Male & 1116 & 6.2787 & 2.3455 & .0702 \\
\cline { 2 - 6 } & Female & 909 & 6.0264 & 2.4249 & .0804 \\
\hline \multirow{2}{*}{ Preference } & Male & 1116 & 6.5081 & 2.3609 & .0707 \\
\cline { 2 - 6 } & Female & 909 & 5.9593 & 2.4367 & .0808 \\
\hline
\end{tabular}

Table S4. Verification of independent samples for gender comparison to shoulder tactile

\begin{tabular}{|c|c|c|c|c|c|c|c|c|c|c|}
\hline & \multicolumn{2}{|c|}{ Levene's test } & \multicolumn{7}{|c|}{ t- verification of equality of means } \\
\hline & & \multirow{2}{*}{$\mathrm{F}$} & \multirow{2}{*}{ Sig. } & \multirow{2}{*}{$\mathrm{t}$} & \multirow{2}{*}{ df } & \multirow{2}{*}{$\begin{array}{c}\text { Sig } \\
\text { (2-tailed) }\end{array}$} & \multirow{2}{*}{$\begin{array}{c}\text { Mean } \\
\text { difference }\end{array}$} & \multirow{2}{*}{$\begin{array}{l}\text { Std. error } \\
\text { difference }\end{array}$} & \multicolumn{2}{|c|}{$\begin{array}{c}95 \% \text { confidence interval } \\
\text { of the difference }\end{array}$} \\
\hline & & & & & & & & & $\begin{array}{l}\text { Lower } \\
\text { Bound }\end{array}$ & $\begin{array}{l}\text { Upper } \\
\text { Bound }\end{array}$ \\
\hline \multirow{2}{*}{ Stiffness } & $\begin{array}{c}\text { Assumed equal } \\
\text { variances }\end{array}$ & 2.748 & .098 & .805 & 2023 & .421 & .1097 & .1364 & -.1578 & .3773 \\
\hline & $\begin{array}{c}\text { Unassuming } \\
\text { equal variances }\end{array}$ & & & .802 & 1912.445 & .423 & .1097 & .1369 & -.1587 & .3783 \\
\hline \multirow{2}{*}{ Stickiness } & $\begin{array}{c}\text { Assumed equal } \\
\text { variances }\end{array}$ & .785 & .376 & 3.009 & 2023 & .003 & .4204 & .1397 & .1464 & .6944 \\
\hline & $\begin{array}{c}\text { Unassuming } \\
\text { equal variances }\end{array}$ & & & 3.003 & 1925.773 & .003 & .4204 & .1399 & .1458 & .6949 \\
\hline \multirow{2}{*}{ Familiarity } & $\begin{array}{c}\text { Assumed equal } \\
\text { variances }\end{array}$ & .410 & .522 & 2.371 & 2023 & .018 & .2523 & .1064 & .0436 & .4609 \\
\hline & $\begin{array}{c}\text { Unassuming } \\
\text { equal variances }\end{array}$ & & & 2.363 & 1914.024 & .018 & .2523 & .1068 & .0429 & .4617 \\
\hline \multirow{2}{*}{ Preference } & $\begin{array}{c}\text { Assumed equal } \\
\text { variances }\end{array}$ & .004 & .948 & 5.128 & 2023 & .000 & .5488 & .1070 & .3389 & .7586 \\
\hline & $\begin{array}{c}\text { Unassuming } \\
\text { equal variances }\end{array}$ & & & 5.111 & 1915.444 & .000 & .5488 & .1074 & .3382 & .7593 \\
\hline
\end{tabular}

Table S5. The independent sample t-test results of elbow tactile sensation by gender

\begin{tabular}{|c|c|c|c|c|c|}
\hline & Gender & $\mathrm{N}$ & mean & Standard deviation & Standard error \\
\hline \multirow{2}{*}{ Stiffness } & Male & 1116 & 6.6756 & 3.2967 & .0987 \\
\cline { 2 - 6 } & Female & 909 & 6.3157 & 3.2746 & .1086 \\
\hline \multirow{2}{*}{ Stickiness } & Male & 1116 & 6.8763 & 3.0504 & .0913 \\
& Female & 909 & 6.6304 & 3.0614 & .1015 \\
\hline \multirow{2}{*}{ Familiarity } & Male & 1116 & 6.5296 & 2.3301 & .0697 \\
\cline { 2 - 6 } & Female & 909 & 6.2629 & 2.3825 & .0790 \\
\hline \multirow{2}{*}{ Preference } & Male & 1116 & 6.6819 & 2.4616 & .0737 \\
\cline { 2 - 6 } & Female & 909 & 6.3520 & 2.4779 & .0822 \\
\hline
\end{tabular}


Table S6. Verification of independent samples for gender comparison to elbow tactile

\begin{tabular}{|c|c|c|c|c|c|c|c|c|c|c|}
\hline & \multicolumn{2}{|c|}{ Levene's test } & \multicolumn{7}{|c|}{ t- verification of equality of means } \\
\hline & & \multirow{2}{*}{$\mathrm{F}$} & \multirow{2}{*}{ Sig. } & \multirow{2}{*}{$\mathrm{t}$} & \multirow{2}{*}{ df } & \multirow{2}{*}{$\begin{array}{c}\text { Sig } \\
\text { (2-tailed) }\end{array}$} & \multirow{2}{*}{$\begin{array}{c}\text { Mean } \\
\text { difference }\end{array}$} & \multirow{2}{*}{$\begin{array}{l}\text { Std. error } \\
\text { difference }\end{array}$} & \multicolumn{2}{|c|}{$\begin{array}{l}95 \% \text { confidence interval } \\
\text { of the difference }\end{array}$} \\
\hline & & & & & & & & & $\begin{array}{l}\text { Lower } \\
\text { Bound }\end{array}$ & Upper Bound \\
\hline \multirow{2}{*}{ Stiffness } & $\begin{array}{l}\text { Assumed equal } \\
\text { variances }\end{array}$ & .004 & .952 & 2.451 & 2023 & .014 & .3599 & .1468 & .0719 & .6478 \\
\hline & $\begin{array}{c}\text { Unassuming equal } \\
\text { variances }\end{array}$ & & & 2.452 & 1946.011 & .014 & .3599 & .1467 & .0720 & .6477 \\
\hline \multirow{2}{*}{ Stickiness } & $\begin{array}{l}\text { Assumed equal } \\
\text { variances }\end{array}$ & .012 & .913 & 1.802 & 2023 & .072 & .2459 & .1365 & -.0217 & .5136 \\
\hline & $\begin{array}{c}\text { Unassuming equal } \\
\text { variances }\end{array}$ & & & 1.801 & 1938.176 & .072 & .2459 & .1365 & -.0218 & .5138 \\
\hline \multirow{2}{*}{ Familiarity } & $\begin{array}{l}\text { Assumed equal } \\
\text { variances }\end{array}$ & .626 & .429 & 2.535 & 2023 & .011 & .2666 & .1051 & .0604 & .4728 \\
\hline & $\begin{array}{c}\text { Unassuming equal } \\
\text { variances }\end{array}$ & & & 2.530 & 1923.301 & .011 & .2666 & .1054 & .0599 & .4733 \\
\hline \multirow{2}{*}{ Preference } & $\begin{array}{l}\text { Assumed equal } \\
\text { variances }\end{array}$ & .121 & .728 & 2.990 & 2023 & .003 & .3298 & .1103 & .1135 & .5461 \\
\hline & $\begin{array}{c}\text { Unassuming equal } \\
\text { variances }\end{array}$ & & & 2.988 & 1935.812 & .003 & .3298 & .1103 & .1133 & .5463 \\
\hline
\end{tabular}

Table S7. Model summary for the shoulder tactile sensation tests

\begin{tabular}{|c|c|c|c|c|}
\hline Model & $\mathrm{R}$ & $\mathrm{R}$ square & Adjusted R square & Std. Error of the Estimate \\
\hline 1 & .567 & .322 & .321 & 1.9867 \\
\hline
\end{tabular}

Table S8. Analysis of variance for the shoulder tactile sensation tests

\begin{tabular}{|c|c|c|c|c|c|c|}
\hline \multicolumn{2}{|c|}{ Model } & Sum of squares(SSR) & $\mathrm{df}$ & Mean square & F & Sig. \\
\hline \multirow{3}{*}{1} & Regression & 3780.176 & 3 & 1260.059 & 319.236 & .000 \\
\cline { 2 - 8 } & Residuals & 7977.108 & 2021 & 3.947 & & \\
\cline { 2 - 8 } & Total & 11757.284 & 2024 & & & \\
\hline
\end{tabular}

Table S9. Coefficients of the multiple regression analysis for the shoulder tactile sensation test

\begin{tabular}{|c|c|c|c|c|c|c|c|c|c|}
\hline & \multirow{2}{*}{ Model } & \multicolumn{2}{|c|}{ Non-standardized coefficient } & \multirow{2}{*}{$\begin{array}{c}\text { Standardized } \\
\text { coefficient }\end{array}$} & \multirow{2}{*}{$\mathrm{t}$} & \multirow{2}{*}{ Sig. } & \multicolumn{3}{|c|}{ Correlations } \\
\hline & & $\mathrm{B}$ & Std. error & & & & Zero- order & Partial & Part \\
\hline \multirow{4}{*}{1} & (constant) & 2.427 & .149 & & 16.326 & .000 & & & \\
\hline & Stiffness & -.061 & .019 & -.078 & -3.305 & .001 & .148 & -.073 & -.061 \\
\hline & Stickiness & .186 & .018 & .242 & 10.120 & .000 & .305 & .220 & .185 \\
\hline & Familiarity & .493 & .019 & .488 & 25.901 & .000 & .532 & .499 & .475 \\
\hline
\end{tabular}

Table S10. Model summary for the elbow tactile sensation tests

\begin{tabular}{|c|c|c|c|c|}
\hline Model & $\mathrm{R}$ & $\mathrm{R}$ square & Adjusted R square & Std. Error of the Estimate \\
\hline 1 & .567 & .322 & .321 & 1.9867 \\
\hline
\end{tabular}


Table S11. Analysis of variance for the elbow tactile sensation tests

\begin{tabular}{|c|c|c|c|c|c|c|}
\hline \multicolumn{2}{|c|}{ Model } & $\begin{array}{c}\text { Sum of squares } \\
(\text { SSR }\end{array}$ & df & Mean square & F & Sig. \\
\hline \multirow{3}{*}{1} & Regression & 3780.176 & 3 & 1260.059 & 319.236 & .000 \\
\cline { 2 - 8 } & Residuals & 7977.108 & 2021 & 3.947 & & \\
\cline { 2 - 8 } & Total & 11757.284 & 2024 & & & \\
\hline
\end{tabular}

Table S12. Coefficients of multiple regression analysis for the elbow tactile sensation tests

\begin{tabular}{|c|c|c|c|c|c|c|c|c|c|}
\hline & \multirow{2}{*}{ Model } & \multicolumn{2}{|c|}{ Non-standardized coefficient } & \multirow{2}{*}{$\begin{array}{c}\begin{array}{c}\text { Standardized } \\
\text { coefficient }\end{array} \\
\text { Beta }\end{array}$} & \multirow{2}{*}{$\mathrm{t}$} & \multirow{2}{*}{ Sig. } & \multicolumn{3}{|c|}{ Correlations } \\
\hline & & B & Std. error & & & & Zero-order & Partial & Part \\
\hline \multirow{4}{*}{1} & (Constant) & 2.427 & .149 & & 16.326 & .000 & & & \\
\hline & Stiffness & -.061 & .019 & -.078 & -3.305 & .001 & .148 & -.073 & -.061 \\
\hline & Stickiness & . 186 & .018 & .242 & 10.120 & .000 & .305 & .220 & .185 \\
\hline & Familiarity & .493 & .019 & .488 & 25.901 & .000 & .532 & .499 & .475 \\
\hline
\end{tabular}


Lab. For Multi-functional of Materials and Devices

\section{젠더에 따른 소프트 로봇 재질의 감성 평가}

과거 기술중심의 산업 패러다임은 인간 기술 중심의 시대를 살 고 있는 인간의 감성에 대한 만족을 불러일으키도록 변화하는 실정 이며, 이에 따라 글로벌 경쟁에서는 기술보다 감성에 의해 우열이 결정되는 시대가 열리고 있습니다. 이는 재료 분야에서도 '감성 소 재'라는 독특한 주제를 이끌어냈습니다.

4차 산업혁명 시대에서 스마트 공장에는 다양한 협업 로봇들이 사용될 것입니다. 이에 따라 로봇에 의한 부딪힘 재해가 발생하며, 이를 방지하기 위하여 소프트 로봇 개념을 도입하였습니다. 단단한 기계를 부드럽게 감싸주는 형태인 소프트 로봇 용 스킨은 젠더에 따라 다른 느낌을 줄 것입니다. 이러한 감성 차이를 파악하는 것은 근로자에게 보다 안전한 근무 환경을 조성하는 데에 큰 역할을 할 것입니다.

이 설문 조사의 목적은 감성소재에 대한 젠더의 영향력을 조사 하는 것입니다. 이는 사용자 집단에 따른 소비자 접근성 파악에 큰 도움이 될 것입니다. 주의 깊게 설문을 읽고 아래의 질문들에 대답 하여 주십시오. 이 조사에 참여해 주셔서 감사드립니다. 


\section{참여자의 개인 정보}

* 아래의 개인정보는 오직 연구적인 목적으로만 사용될 것이며, 다른 목적이나 제 3 의 단체와는 공유되지 않을 것입니다.
* 나이 : 만 세
성별:
(1) 남 (2)여

* 이 설문은 로봇에 의한 부딪힘 재해 등을 방지하기 위한 소프트 스킨 제작을 목적으로 합니다. 아래의 사진을 참고하여, 샘플로 감싼 로봇과 부딪힐 때의 상황을 떠올리며 답변하시면 도움이 될 것입니다.

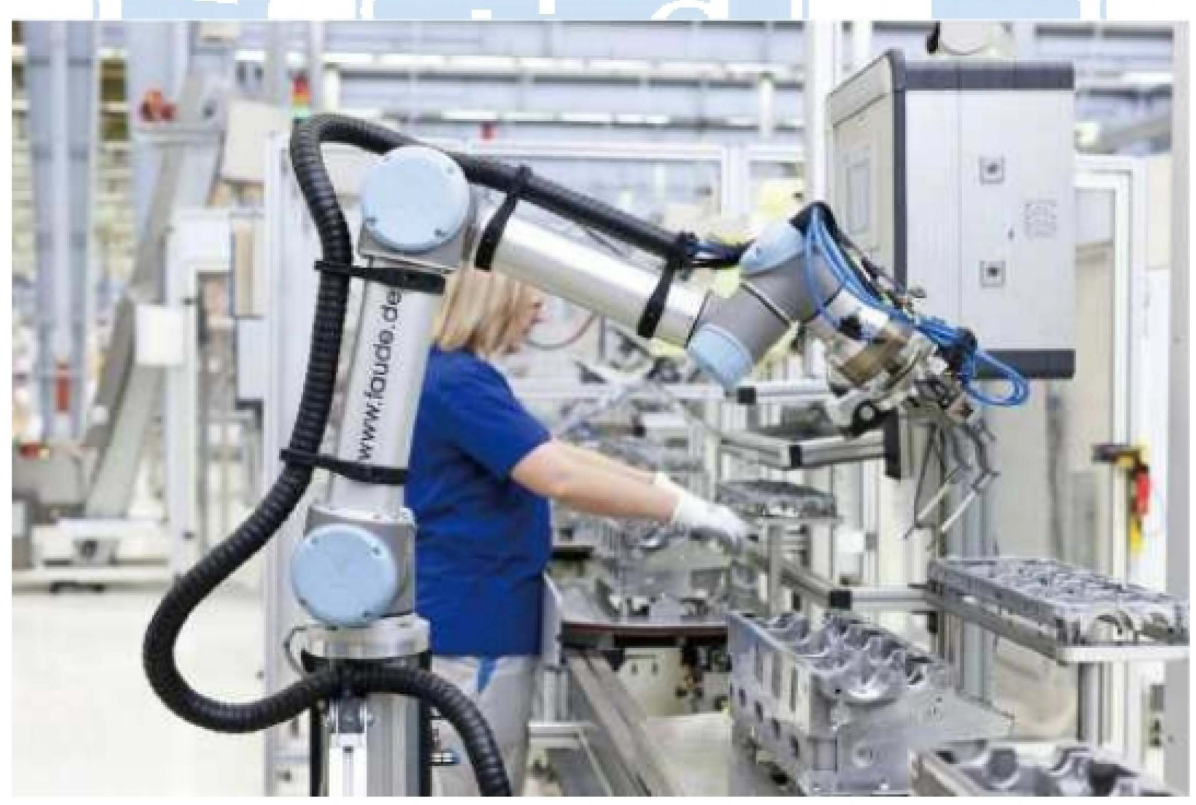


Lab. For Multi-functional of Materials and Devices Department of Material Science \& Chemical Engineering

Hanyang University

\section{설문 방법}

설문은 촉각(어깨)+시각, 촉각(팔꿈치)+시각의 2 가지 영역으로 이 루어져 있습니다.

* 각 영역은 9 가지 시편에 대해 최대 6 가지의 질문을 포함하고 있습 니다.

* 객관식 항목의 경우 해당하는 점수에 $\mathrm{O}$ 표를 해주시면 됩니다.

\section{평가 항목에 대한 설명}

\begin{tabular}{|c|l|}
\hline 항목명 & \multicolumn{1}{|c|}{ 설명 } \\
\hline 단단함 & $\begin{array}{l}\text { 해당 감각만을 사용하여 각 시편에 충격이 가해질 } \\
\text { 경우 얼마나 단단할 것처럼 느껴지는지 선택 }\end{array}$ \\
\hline 끈적임 & $\begin{array}{l}\text { 해당 감각만을 사용하여 각 시편이 얼마나 끈적일 } \\
\text { 것처럼 느껴지는지 선택 }\end{array}$ \\
\hline 재료의 & $\begin{array}{l}\text { 해당 감각만을 사용하여 각 시편이 신체에 닿았을 } \\
\text { 댁숙함 }\end{array}$ \\
\hline 선호마나 익숙한 재료인지 선택
\end{tabular}


Lab. For Multi-functional of Materials and Devices

Department of Material Science \& Chemical Engineering

Hanyang University

\section{1. 촉각(어깨)}

- 아래의 재료를 어깨에 부딪혔을 때 어떻게 느껴지는지 체크해주세요.

가. 샘플 1

\begin{tabular}{|c|ccccccccccccc|}
\hline 평가 항목 & \multicolumn{110}{|c|}{ 점수 } \\
\hline 단단함 & 물렁함 & -5 & -4 & -3 & -2 & -1 & 0 & 1 & 2 & 3 & 4 & 5 & 단단함 \\
\hline 끈적임 & 끈적임 & -5 & -4 & -3 & -2 & -1 & 0 & 1 & 2 & 3 & 4 & 5 & $\begin{array}{c}\text { 끈적이지 } \\
\text { 않음 }\end{array}$ \\
\hline $\begin{array}{c}\text { 재료의 } \\
\text { 익숙함 }\end{array}$ & 낮섦 & -5 & -4 & -3 & -2 & -1 & 0 & 1 & 2 & 3 & 4 & 5 & 익숙함 \\
\hline 선호도 & 불호 & -5 & -4 & -3 & -2 & -1 & 0 & 1 & 2 & 3 & 4 & 5 & 선호 \\
\hline
\end{tabular}

나. 샘플 2

\begin{tabular}{|c|cccccccccccc|c|}
\hline 평가 항목 & \multicolumn{10}{|c|}{ 점수 } \\
\hline 단단함 & 물렁함 & -5 & -4 & -3 & -2 & -1 & 0 & 1 & 2 & 3 & 4 & 5 & 단단함 \\
\hline 끈적임 & 끈적임 & -5 & -4 & -3 & -2 & -1 & 0 & 1 & 2 & 3 & 4 & 5 & $\begin{array}{c}\text { 끈적이지 } \\
\text { 않음 }\end{array}$ \\
\hline $\begin{array}{c}\text { 재료의 } \\
\text { 익숙함 }\end{array}$ & 낮섦 & -5 & -4 & -3 & -2 & -1 & 0 & 1 & 2 & 3 & 4 & 5 & 익숙함 \\
\hline 선호도 & 불호 & -5 & -4 & -3 & -2 & -1 & 0 & 1 & 2 & 3 & 4 & 5 & 선호 \\
\hline
\end{tabular}

다. 샘플 3

\begin{tabular}{|c|ccccccccccccc|}
\hline 평가 항목 & \multicolumn{110}{|c|}{ 점수 } \\
\hline 단단함 & 물렁함 & -5 & -4 & -3 & -2 & -1 & 0 & 1 & 2 & 3 & 4 & 5 & 단단함 \\
\hline 끈적임 & 끈적임 & -5 & -4 & -3 & -2 & -1 & 0 & 1 & 2 & 3 & 4 & 5 & $\begin{array}{c}\text { 끈적이지 } \\
\text { 않음 }\end{array}$ \\
\hline
\end{tabular}


Lab. For Multi-functional of Materials and Devices

Department of Material Science \& Chemical Engineering

Hanyang University

\begin{tabular}{|l|lllllllllllll|}
\hline $\begin{array}{l}\text { 재료의 } \\
\text { 익숙함 }\end{array}$ & 낯섦 & -5 & -4 & -3 & -2 & -1 & 0 & 1 & 2 & 3 & 4 & 5 & 익숙함 \\
\hline 선호도 & 불호 & -5 & -4 & -3 & -2 & -1 & 0 & 1 & 2 & 3 & 4 & 5 & 선호 \\
\hline
\end{tabular}

라. 샘플 4

\begin{tabular}{|c|ccccccccccccc|}
\hline 평가 항목 & \multicolumn{10}{|c|}{ 점수 } \\
\hline 단단함 & 물렁함 & -5 & -4 & -3 & -2 & -1 & 0 & 1 & 2 & 3 & 4 & 5 & 단단함 \\
\hline 끈적임 & 끈적임 & -5 & -4 & -3 & -2 & -1 & 0 & 1 & 2 & 3 & 4 & 5 & $\begin{array}{c}\text { 끈적이지 } \\
\text { 않음 }\end{array}$ \\
\hline $\begin{array}{c}\text { 재료의 } \\
\text { 익숙함 }\end{array}$ & 낮섦 & -5 & -4 & -3 & -2 & -1 & 0 & 1 & 2 & 3 & 4 & 5 & 익숙함 \\
\hline 선호도 & 불호 & -5 & -4 & -3 & -2 & -1 & 0 & 1 & 2 & 3 & 4 & 5 & 선호 \\
\hline
\end{tabular}

마. 샘플 5

\begin{tabular}{|c|ccccccccccccc|}
\hline 평가 항목 & \multicolumn{10}{|c|}{ 점수 } \\
\hline 단단함 & 물렁함 & -5 & -4 & -3 & -2 & -1 & 0 & 1 & 2 & 3 & 4 & 5 & 단단함 \\
\hline 끈적임 & 끈적임 & -5 & -4 & -3 & -2 & -1 & 0 & 1 & 2 & 3 & 4 & 5 & $\begin{array}{c}\text { 끈적이지 } \\
\text { 않음 }\end{array}$ \\
\hline $\begin{array}{c}\text { 재료의 } \\
\text { 익숙함 }\end{array}$ & 낮섦 & -5 & -4 & -3 & -2 & -1 & 0 & 1 & 2 & 3 & 4 & 5 & 익숙함 \\
\hline 선호도 & 불호 & -5 & -4 & -3 & -2 & -1 & 0 & 1 & 2 & 3 & 4 & 5 & 선호 \\
\hline
\end{tabular}

바. 샘플 6

\begin{tabular}{|c|cccccccccccccc|}
\hline 평가 항목 & \multicolumn{110}{|c|}{ 점수 } \\
\hline 단단함 & 물렁함 & -5 & -4 & -3 & -2 & -1 & 0 & 1 & 2 & 3 & 4 & 5 & & 단단함 \\
\hline
\end{tabular}


Lab. For Multi-functional of Materials and Devices

Department of Material Science \& Chemical Engineering

Hanyang University

\begin{tabular}{|l|ccccccccccccc|}
\hline 끈적임 & 끈적임 & -5 & -4 & -3 & -2 & -1 & 0 & 1 & 2 & 3 & 4 & 5 & $\begin{array}{c}\text { 끈적이지 } \\
\text { 않음 }\end{array}$ \\
\hline $\begin{array}{l}\text { 재료의 } \\
\text { 익숙함 }\end{array}$ & 낯섦 & -5 & -4 & -3 & -2 & -1 & 0 & 1 & 2 & 3 & 4 & 5 & 익숙함 \\
\hline 선호도 & 불호 & -5 & -4 & -3 & -2 & -1 & 0 & 1 & 2 & 3 & 4 & 5 & 선호 \\
\hline
\end{tabular}

사. 샘플 7

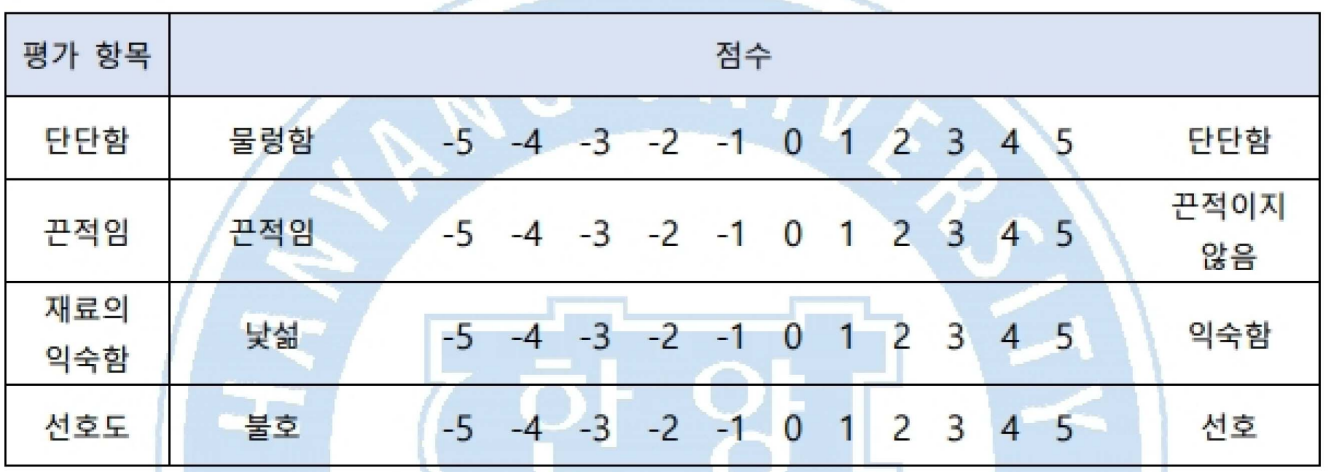

아. 샘플 8

\begin{tabular}{|c|ccccccccccccc|}
\hline 평가 항목 & \multicolumn{10}{|c|}{ 점수 } \\
\hline 단단함 & 물렁함 & -5 & -4 & -3 & -2 & -1 & 0 & 1 & 2 & 3 & 4 & 5 & 단단함 \\
\hline 끈적임 & 끈적임 & -5 & -4 & -3 & -2 & -1 & 0 & 1 & 2 & 3 & 4 & 5 & $\begin{array}{c}\text { 끈적이지 } \\
\text { 않음 }\end{array}$ \\
\hline $\begin{array}{c}\text { 재료의 } \\
\text { 익숙함 }\end{array}$ & 낮섦 & -5 & -4 & -3 & -2 & -1 & 0 & 1 & 2 & 3 & 4 & 5 & 익숙함 \\
\hline 선호도 & 불호 & -5 & -4 & -3 & -2 & -1 & 0 & 1 & 2 & 3 & 4 & 5 & 선호 \\
\hline
\end{tabular}

자. 샘플 9

\begin{tabular}{|l|l}
\hline 평가 항목 & 점수
\end{tabular}

6 
Lab. For Multi-functional of Materials and Devices

Department of Material Science \& Chemical Engineering

Hanyang University

\begin{tabular}{|c|ccccccccccccc|}
\hline 단단함 & 물렁함 & -5 & -4 & -3 & -2 & -1 & 0 & 1 & 2 & 3 & 4 & 5 & 단단함 \\
\hline 끈적임 & 끈적임 & -5 & -4 & -3 & -2 & -1 & 0 & 1 & 2 & 3 & 4 & 5 & $\begin{array}{c}\text { 끈적이지 } \\
\text { 않음 }\end{array}$ \\
\hline $\begin{array}{c}\text { 재료의 } \\
\text { 익숙함 }\end{array}$ & 낮섦 & -5 & -4 & -3 & -2 & -1 & 0 & 1 & 2 & 3 & 4 & 5 & 익숙함 \\
\hline 선호도 & 불호 & -5 & -4 & -3 & -2 & -1 & 0 & 1 & 2 & 3 & 4 & 5 & 선호 \\
\hline
\end{tabular}

\section{2. 촉각(팔꿈치)}

- 아래의 재료를 팔꿈치로 눌렀을 때 어떻게 느껴지는지 체크해주세요.

가. 샘플 1

\begin{tabular}{|c|c|cccccccc|cccc|c|}
\hline 평가 항목 & \multicolumn{110}{|c|}{ 점수 } \\
\hline 단단함 & 물렁함 & -5 & -4 & -3 & -2 & -1 & 0 & 1 & 2 & 3 & 4 & 5 & 단단함 \\
\hline 끈적임 & 끈적임 & -5 & -4 & -3 & -2 & -1 & 0 & 1 & 2 & 3 & 4 & 5 & $\begin{array}{c}\text { 끈적이지 } \\
\text { 않음 }\end{array}$ \\
\hline $\begin{array}{c}\text { 재료의 } \\
\text { 익숙함 }\end{array}$ & 낯섦 & -5 & -4 & -3 & -2 & -1 & 0 & 1 & 2 & 3 & 4 & 5 & 익숙함 \\
\hline 선호도 & 불호 & -5 & -4 & -3 & -2 & -1 & 0 & 1 & 2 & 3 & 4 & 5 & 선호 \\
\hline
\end{tabular}

나. 샘플 2

\begin{tabular}{|c|ccccccccccccc|}
\hline 평가 항목 & \multicolumn{110}{|c|}{ 점수 } \\
\hline 단단함 & 물렁함 & -5 & -4 & -3 & -2 & -1 & 0 & 1 & 2 & 3 & 4 & 5 & 단단함 \\
\hline 끈적임 & 끈적임 & -5 & -4 & -3 & -2 & -1 & 0 & 1 & 2 & 3 & 4 & 5 & $\begin{array}{c}\text { 끈적이지 } \\
\text { 않음 }\end{array}$ \\
\hline $\begin{array}{c}\text { 재료의 } \\
\text { 익숙함 }\end{array}$ & 낮섦 & -5 & -4 & -3 & -2 & -1 & 0 & 1 & 2 & 3 & 4 & 5 & 익숙함 \\
\hline 선호도 & 불호 & -5 & -4 & -3 & -2 & -1 & 0 & 1 & 2 & 3 & 4 & 5 & 선호 \\
\hline
\end{tabular}


Lab. For Multi-functional of Materials and Devices

Department of Material Science \& Chemical Engineering

Hanyang University

\section{다. 샘플 3}

\begin{tabular}{|c|ccccccccccccc|}
\hline 평가 항목 & \multicolumn{10}{|c|}{ 점수 } \\
\hline 단단함 & 물렁함 & -5 & -4 & -3 & -2 & -1 & 0 & 1 & 2 & 3 & 4 & 5 & 단단함 \\
\hline 끈적임 & 끈적임 & -5 & -4 & -3 & -2 & -1 & 0 & 1 & 2 & 3 & 4 & 5 & $\begin{array}{c}\text { 끈적이지 } \\
\text { 않음 }\end{array}$ \\
\hline $\begin{array}{c}\text { 재료의 } \\
\text { 익숙함 }\end{array}$ & 낮섦 & -5 & -4 & -3 & -2 & -1 & 0 & 1 & 2 & 3 & 4 & 5 & 익숙함 \\
\hline 선호도 & 불호 & -5 & -4 & -3 & -2 & -1 & 0 & 1 & 2 & 3 & 4 & 5 & 선호 \\
\hline
\end{tabular}

라. 샘풀 4

\begin{tabular}{|c|c|cccccccccccc|}
\hline 평가 항목 & \multicolumn{110}{|c|}{ 점수 } \\
\hline 단단함 & 물렁함 & -5 & -4 & -3 & -2 & -1 & 0 & 1 & 2 & 3 & 4 & 5 & 단단함 \\
\hline 끈적임 & 끈적임 & -5 & -4 & -3 & -2 & -1 & 0 & 1 & 2 & 3 & 4 & 5 & $\begin{array}{c}\text { 끈적이지 } \\
\text { 않음 }\end{array}$ \\
\hline $\begin{array}{c}\text { 재료의 } \\
\text { 익숙함 }\end{array}$ & 낮섦 & -5 & -4 & -3 & -2 & -1 & 0 & 1 & 2 & 3 & 4 & 5 & 익숙함 \\
\hline 선호도 & 불호 & -5 & -4 & -3 & -2 & -1 & 0 & 1 & 2 & 3 & 4 & 5 & 선호 \\
\hline
\end{tabular}

마. 샘플 5

\begin{tabular}{|c|ccccccccccccc|}
\hline 평가 항목 & \multicolumn{110}{|c|}{ 점수 } \\
\hline 단단함 & 물렁함 & -5 & -4 & -3 & -2 & -1 & 0 & 1 & 2 & 3 & 4 & 5 & 단단함 \\
\hline 끈적임 & 끈적임 & -5 & -4 & -3 & -2 & -1 & 0 & 1 & 2 & 3 & 4 & 5 & $\begin{array}{c}\text { 끈적이지 } \\
\text { 않음 }\end{array}$ \\
\hline $\begin{array}{c}\text { 재료의 } \\
\text { 익숙함 }\end{array}$ & 낮섦 & -5 & -4 & -3 & -2 & -1 & 0 & 1 & 2 & 3 & 4 & 5 & 익숙함 \\
\hline
\end{tabular}


Lab. For Multi-functional of Materials and Devices

Department of Material Science \& Chemical Engineering

Hanyang University

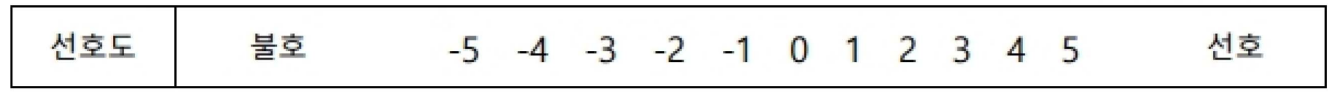

바. 샘플 6

\begin{tabular}{|c|ccccccccccccc|}
\hline 평가 항목 & \multicolumn{10}{|c|}{ 점수 } \\
\hline 단단함 & 물렁함 & -5 & -4 & -3 & -2 & -1 & 0 & 1 & 2 & 3 & 4 & 5 & 단단함 \\
\hline 끈적임 & 끈적임 & -5 & -4 & -3 & -2 & -1 & 0 & 1 & 2 & 3 & 4 & 5 & $\begin{array}{c}\text { 끈적이지 } \\
\text { 않음 }\end{array}$ \\
\hline $\begin{array}{c}\text { 재료의 } \\
\text { 익숙함 }\end{array}$ & 낮섦 & -5 & -4 & -3 & -2 & -1 & 0 & 1 & 2 & 3 & 4 & 5 & 익숙함 \\
\hline 선호도 & 불호 & -5 & -4 & -3 & -2 & -1 & 0 & 1 & 2 & 3 & 4 & 5 & 선호 \\
\hline
\end{tabular}

사. 샘플 7

\begin{tabular}{|c|ccccccccccccc|}
\hline 평가 항목 & \multicolumn{10}{|c|}{ 점수 } \\
\hline 단단함 & 물렁함 & -5 & -4 & -3 & -2 & -1 & 0 & 1 & 2 & 3 & 4 & 5 & 단단함 \\
\hline 끈적임 & 끈적임 & -5 & -4 & -3 & -2 & -1 & 0 & 1 & 2 & 3 & 4 & 5 & $\begin{array}{c}\text { 끈적이지 } \\
\text { 않음 }\end{array}$ \\
\hline $\begin{array}{c}\text { 재료의 } \\
\text { 익숙함 }\end{array}$ & 낮섦 & -5 & -4 & -3 & -2 & -1 & 0 & 1 & 2 & 3 & 4 & 5 & 익숙함 \\
\hline 선호도 & 불호 & -5 & -4 & -3 & -2 & -1 & 0 & 1 & 2 & 3 & 4 & 5 & 선호 \\
\hline
\end{tabular}

아. 샘플 8

\begin{tabular}{|c|ccccccccccccc|}
\hline 평가 항목 & \multicolumn{110}{|c|}{ 점수 } \\
\hline 단단함 & 물렁함 & -5 & -4 & -3 & -2 & -1 & 0 & 1 & 2 & 3 & 4 & 5 & 단단함 \\
\hline 끈적임 & 끈적임 & -5 & -4 & -3 & -2 & -1 & 0 & 1 & 2 & 3 & 4 & 5 & $\begin{array}{c}\text { 끈적이지 } \\
\text { 않음 }\end{array}$ \\
\hline
\end{tabular}


Lab. For Multi-functional of Materials and Devices

Department of Material Science \& Chemical Engineering

Hanyang University

\begin{tabular}{|l|lllllllllllll|}
\hline $\begin{array}{l}\text { 재료의 } \\
\text { 익숙함 }\end{array}$ & 낯섦 & -5 & -4 & -3 & -2 & -1 & 0 & 1 & 2 & 3 & 4 & 5 & 익숙함 \\
\hline 선호도 & 불호 & -5 & -4 & -3 & -2 & -1 & 0 & 1 & 2 & 3 & 4 & 5 & 선호 \\
\hline
\end{tabular}

자. 샘플 9

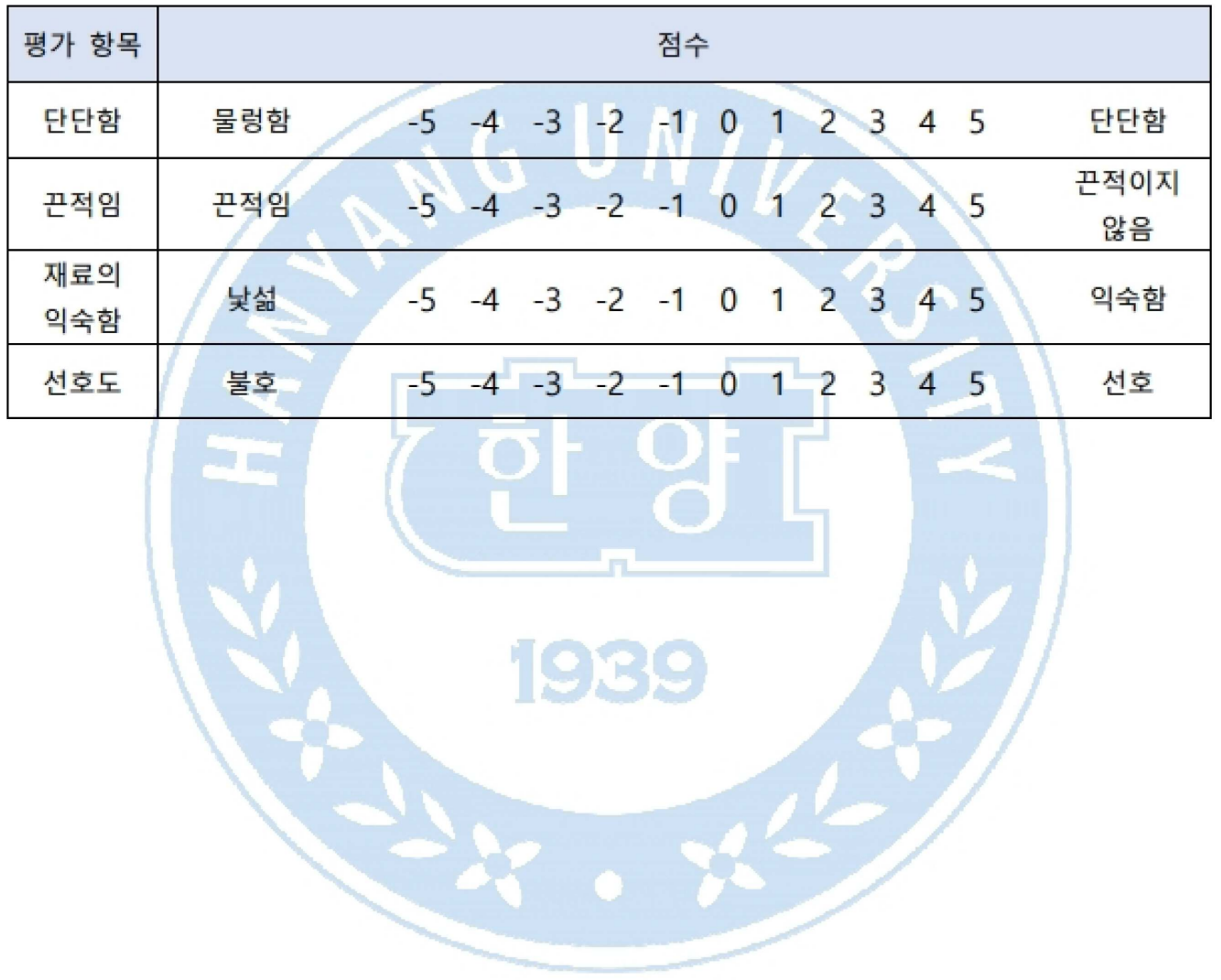


Lab. For Multi-functional of Materials and Devices Department of Material Science \& Chemical Engineering Hanyang University

\section{설문에 대해 다른 의견이 있다면 아래에 적어주십시오.}

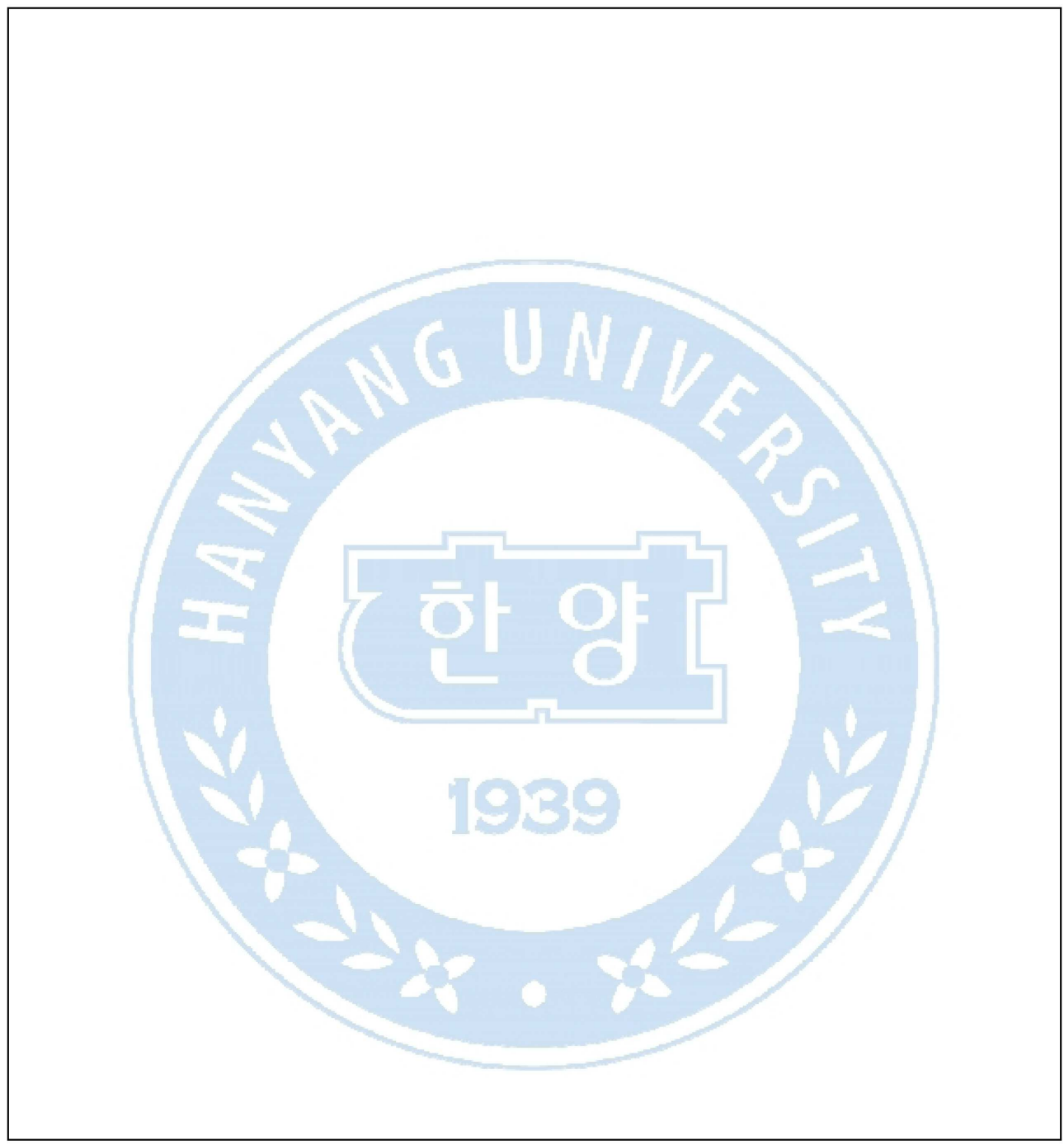

설문에 참여해 주셔서 진심으로 감사드립니다. 